\title{
KAJIANTEOLOGIS-PEDAGOGIS MENYANGKUT KEYAKINAN GURU PAK MEMAHAMI OTORITAS ALKITAB DALAM PENGAJARANNYA
}

\author{
A Dan Kia \\ Universitas Kristen Indonesia \\ dannqh_dan@yahoo.co.id
}

\begin{abstract}
ABSTRAK
Penulisan ini merupakan kajian teologis-pedagogis menyangkut keyakinan guru PAK memahami otoritas Alkitab dalam pengajarannya. Iman yang disertai perbuatan baik, menghasilkan keyakinan yang tidak perlu diragukan dalam kepribadian seorang guru, menyangkut keyakinan dalam melaksanakan tugas pengajaran. Melalui aktifitasnya seorang guru memahami bagaimana menempatkan Alkitab sebagai otoritas tertinggi dalam setiap pengajarannya, agar memiliki kualifikasi yang terbaik. Hal ini dapat dicapai hanya dengan mengikuti aturan yang dikehendaki Tuhan bagi setiap orang yang mengandalkan-Nya sebagai Guru Agung. Dengan demikian, maka peserta didik akan menjadi semakin bertumbuh, karena guru yang mengajar adalah guru yang memahami benar tentang kebenaran Allah melalui firman Tuhan sebagai otoritas tertinggi dan sebagai dasar dari sumber ilmu pengetahuan.

Perkembangan jaman yang demikian pesat, mengharuskan setiap orangtua dan guru PAK agar selalu mengandalkan Tuhan dalam tindakannya sebagai seorang pendidik. Pada setiap kegiatan mengajar dan persiapan seorang guru PAK tidak terlepas dari pengharapannya kepada Tuhan melalui kebenaran yang hakiki tersebut. Semua hal ini sangat berpengaruh dalam proses pengajaran bagaimana mendidik dan mengarahkan perserta didik dengan benar. Perkembangan ini dapat dilihat dari tumbuh kembangnya setiap peserta didik sesuai sesuai dengan proses yang ada. Guru PAK memahami benar tentang kehendak Allah melalui kebenaran yang sejati. Peserta didik akan dibawa kepada kebenaran yang baik, dan kekuasaan Tuhan akan berpengaruh terhadap pribadi mereka, dikarenakan guru PAK selalu mengandalkan Tuhan dalam setiap kegiatan pengajarannya. Perlu ada pemahaman yang jelas tentang bagaimana mendisain hidup, kepada siapa disain itu dipercaya jika tidak dimulai dari guru sebagai orangtua kedua di sekolah. Hal ini akan terjadi suatu perubahan jika guru tersebut selalu mengandalkan Tuhan dalam setiap tindakan hidupnya, dan tindakan itu akan berpengaruh bagi peserta didik yang dididiknya.

Melalui penulisan ini, maka penulis berpikir untuk suatu kemajuan dalam proses belajar mengajar apabila guru PAK selalu memiliki relasi yang baik antar dirinya dengan Sang Guru Agung, maka guru PAK dapat memahami Alkitab menjawab kenyataan setiap permasalahan yang terjadi dalam dunia pendidikan Kristen, karena Alkitab adalah jawaban terbaik pada masa kini dan masa akan datang, sebab di dalamnya memberikan suatu perubahan bagi setiap manusia, dan bagi guru PAK sebagai pelaku kebenaran dan contoh bagi peserta didik, Yesaya 43:7 ; Efesus 2:10.

Penulisan ini dilakukan melalui penelitian kepustakaan (library reseach). Penelitian ini menyangkut keyakinan guru PAK dalam tindakan pengajarannya yang harus berorientasi pada Alkitab sebagai otoritas tertinggi, dapat terjawab apabila guru PAK mampu melihat setiap permasalahan dalam pengajaran menurut prespektif iman Kristen.
\end{abstract}

Kata kunci: Keyakinan Guru, Pendidikan Agama Kristen, Kajian Teologis-Pedagogis. 


\section{Pendahuluan}

Keyakinan guru PAK meyangkut otoritas Alkitab dalam pengajarannya dapat membawa perubahan karakter bagi pengajar dan peserta didik, serta adanya peningkatan spiritual, karena guru mengenal Allah di dalam Yesus Kristus melalui pemahaman Alkitab, dalam kehidupan dan pengajarannya setiap hari. Pokok-pokok ini dibahas karena Alkitab adalah firman Allah yang memiliki otoritas tertinggi bagi pengajaran PAK.

Alkitab merupakan titik awal dari semua studi, sebagaimana yang tertera di dalam 2 Timotius 3:16-17 yang mengajarkan bahwa Alkitab berotoritas mutlak, karena Alkitab itu diwahyukan oleh Allah, 2 Petrus 1:21, sehingga tidak mungkin ada otoritas lain lebih tinggi, karena itu umat kristiani meyakini Alkitab sebagai otoritas tertinggi dalam kehidupan.

Seorang pengajar Kristen sebelum ia mengajar, terlebih dahulu perlu mengetahui dan meyakini otoritas Alkitab dalam pengajarannya, karena tidak mungkin memaksakan peserta didik untuk mengerti dan melakukan apa yang diajarkan. Alkitab memiliki kuasa untuk mempengaruhi orang yang membacanya. John.R.W. Stott mengatakan, "otoritasnya bukan sesuatu yang memaksakan diri dari atas, tetapi sesuatu yang menyebabkan penerima wajar dari bawah, secara tak terduga, otoritas itu memerdekakan". 1 Pemahaman ini memberikan suatu pengertian bahwa seorang guru PAK percaya Alkitab yang adalah firman Allah dan berotoritas, Allah berdaulat atas perkataan yang disampaikannya. Sebagai contoh Lukas 5:6 melalui pengajaran Yesus, ketika Ia bertemu dengan Simon

\footnotetext{
${ }^{1}$ John.R.W. Stott, Memahami Isi Alkitab (Jakarta: Persekutuan Pembaca Alkitab, 1994), 147.
}

Petrus di Galilea. Yesus memerintahkan Petrus untuk bertolak ketempat yang dalam dan melemparkan jalanya kembali. Tetapi Petrus dengan keterampilan berbekal dan pengalaman sebagai nelayan selama bertahun-tahun menolak usulan Yesus, dan bahkan menentang dengan menyatakan, "Guru, setelah sepanjang malam kami bekerja keras dan kami tidak menangkap apa-apa" tetapi dengan hikmat Tuhan, Petrus mengatakan, tetapi "Engkau yang mengatakannya, aku akan menebarkan jala juga.

Dasar otoritas Alkitab adalah Alkitab sendiri yang mutlak benar dan kekal (Mzm. 119;:89-160), isinya sempurna (Mzm. 19:7), dan perintahnya suci, baik, benar (Rm. 7:12). Berdasarkan ayat-ayat ini jelaslah bahwa otoritas Alkitab itu berpusat pada kebenaran, kekekalan dan perintah Allah. Hendaknya guru PAK dalam pengajarannya percaya bahwa Alkitab bukan hanya otoritas dalam kata-kata saja, melainkan juga dalam kehidupan nyata. $^{2}$ Kebenaran Allah bukan hanya dalam bentuk tertulis saja, tetapi kebenaran Allah itu dalam bentuk nyata melalui Yesus Kristus. Dengan suatu tujuan untuk membenarkan manusia dari keberdosaannya dihadapan Allah, sehingga Yesus yang adalah Tuhan memberikan pengampunan kepada manusia berdosa dan melayakannya menjadi manusia yang dibenarkan (bnd. Rm. 3:22-24). Starr Meade yang adalah seorang guru dan juga sebagai penulis mengatakan, "pembenaran adalah tindakan anugerah Allah cuma-cuma, yang dengannya Dia mengampuni semua dosa kita sebagai orang-orang yang benar dalam pandangan-Nya". 3

\footnotetext{
${ }^{2}$ W. Crampton, Alkitab: Firman Allah (Surabaya: Momentum, 2005), 59.

3 Starr Meade,Treaning Harts Teching Minds (Surabaya: Momentum, 2004), 139.
} 
Alkitab mendapat posisi istimewa karena pertama, pengetahuan aktual tentang Allah hanya terdapai di dalam Alkitab, kedua, Alkitab merupakan standar untuk menilai doktrin yang benar dan yang palsu, ketiga, tanpa Alkitab kita akan jatuh ke dalam kesalahpahaman tentang Allah. Keempat, Alkitab menyingkapkan apa yang tidak dikomunikasikan Allah melalui ciptaanNya. Oleh karena itu Alkitab memiliki kedudukan atau otoritas lebih tinggi dari gereja. Alkitab bukan berdiri atas gereja melainkan Alkitab berdiri atas Allah.

Marttin Luther menyadari bahwa, "otoritas hanya terdapat pada Alkitab. Oleh karena dari Alkitab kita peroleh pengharapan iman. Iman pengharapan berdasarkan Alkitab, otoritas tertinggi karena diwahyukan oleh Allah, Jika tidak ada firman Tuhan, maka kita akan kehilangan otoritas yang sejati, itulah sebabnya kita kembali kepada otoritas Alkitab". ${ }^{4}$ Artinya bahwa hanya Alkitab sendiri yang memiliki otoritas tertinggi di dunia. Jadi pendapat Yohanes Calvin dan Luther Alkitab memiliki ototritas.

Berdasarkan kedua pendapat di atas, terdapat perbedaan pendapat antara gereja katolik dan kedua tokoh Reformasi tentang otoritas Alkitab. Penulis setuju dengan pendapat dari tokoh Reformasi bahwa otoritas Alkitab lebih tinggi dari gereja sebab tanpa firman Allah, maka tidak ada gereja. Yesus berkata segala tulisan termasuk tulisan Musa berasal dari Tuhan.

Sebagai guru PAK perlu mengakui dan percaya otoritas Alkitab yang bersumber dari Allah. Jadi yang dimaksud dengan mempercayai otoritas Alkitab dalam pengajaran PAK itu adalah mempercayakan kuasa Allah melalui Yesus

\footnotetext{
${ }^{4}$ Stephen Tong, Seri Teologi Reformasi dan Teologi Reformed (Jakarta: Lembaga Reformed Injili Indonesia, 1999), 11.
}

Kristus di setiap materi yang diajarkan dan bukan kuasa dari penulis kitab-kitab tersebut.

\section{Mengutamakan Alkitab dalam Pengajaran}

Dalam Pendidikan Agama Kristen, Alkitab adalah sumber utama pengajaran, karena dilihat dari tujuan pengajaran agama Kristen yaitu memperkenalkan Allah kepada peserta didik dan itu hanya tertera dalam Alkitab. Kalau diteliti secara mendalam, khusus-nya pada kitab Kejadian 1-2, manusia pertama Adam dan Hawa tidak mengenal firman yang tertulis (seperti yang dimiliki orang percaya pada saat ini), mengapa demikian karena Allah secara lisan berbicara langsung kepada mereka, dan firman itu tertanam dalam loh hati mereka, akan tetapi Adam dan Hawa jatuh kedalam dosa karena tidak taat kepada firman Allah secara lisan, dan telah dihukum oleh Allah. Namun Allah dengan penuh kasihNya memanggil manusia untuk kembali kepada-Nya. Di sinilah manusia membutuhkan firman secara tertulis untuk menolong manusia memahami tentang rencana Allah yang sempurna.

Pengajaran yang benar berasal dari Allah, namun sejak manusia jatuh dalam dosa, Allah memberikan pengajaran kepada Abraham, Ishak dan Yakub untuk meneruskan. Homrighausen, E.G., Enklaar, I.H, mengatakan: Nenek moyang kaum Israel, Abraham Ishak dan Yakub menjadi guru dalam keluarganya. Sebagai bapa dari bangsa-bangsa, mereka bukan saja menjadi imam yang merupakan pegantara antara Tuhan dengan umat$\mathrm{Nya}$, tetapi juga menjadi guru yang mengajarkan tentang perbuatan-perbuatan Tuhan yang mulia itu dengan segala janji Tuhan yang membawa berkat kepada Israel turu temurun. Tuhan telah memilih 
dan memanggil Abraham dari jauh untuk melayani kehendak-Nya yang agung itu, guna keselamatan manusia. ${ }^{5}$

Pengajaran Abraham berdasarkan firman Tuhan secara lisan diberikan langsung oleh Allah. Setelah Abraham meninggal, Allah memilih Ishak dan segala keturunannya untuk meneruskan pengajaran PAK. Homrighausen, E.G. dan Enklaar, I.H, mengatakan: Ishak meneruskan pengajaran-pengajaran yang penting itu dan kemudian anaknya Yakub pula menanamkan segala perkara ini ke dalam batin anaknya. Yusuf menyimpan pengajaran-pengajaran itu dalam hatinya, kemana saja ia pergi, biar dalam pengasingan sekalipun, sehingga pengetahuan akan janji Tuhan itu tetap terpelihara oleh bangsa Israel. ${ }^{6}$

Allah tetap mengasihi bangsa Israel, yang walaupun bangsa Israel tetap mengeraskan hati mereka untuk ditegur dan diajar oleh firman Tuhan. Allah memilih Musa untuk tetap mengajar dan bahkan membebaskan mereka dari penindasan bangsa Mesir. Pengajaran PAK menjadi warisan bagi para nabi dan raja-raja Israel. Mereka mengajarkan firman Tuhan dengan rajin dan setia supaya umat Israel kembali kepada sumber keselamatannya. ${ }^{7}$ Demikian pula dalam Perjanjian Baru, segala kitab ditulis dengan tujuan-tujuan tertentu, ialah untuk mengajar umat Kristen tentang pernyataan Allah dalam Yesus.

Guru PAK sepatutnya selalu menyejajarkan setiap pengetahuan yang dipelajari dan diajarkannya harus berdasarkan Alkitab, baik melalui Perjanjian Lama dan Perjanjian Baru. Dengan demikian, maka peran dan kuasa Allah

\footnotetext{
${ }^{5}$ Homrighausen, E.G., Enklaar, I.H, Pendidikan Agama Kristen(Jakarta: BPK Gunung Mulia, 2009), 2-3.

${ }^{6}$ Ibid.,

${ }^{7}$ Ibid
}

berlaku dalam setiap akitivitas pengajaran, sehingga peserta didik diberkati bukan saja karena materi yang diberikan, tetapi kuasa Tuhan yang bekerja. Dalam konteks Perjanjian Baru, Yesus sebagai guru, umumnya diperhatikan dan dipuji oleh orang Yahudi; mereka sendiri menyebut Dia "Rabbi". ${ }^{8}$ Dalam pengajaran Yesus, Yesus mengajar di mana saja, di atas bukit, di dalam perahu, di tepi sumur dalan lain-lain. Yesus mengajar tidak memerlukan sekolah atau gedung, tetapi keadaan dan pertemuan digunakanNya untuk menyampaikan firman Allah. ${ }^{9}$

Setelah Yesus selesai melakukan misiNya di dunia, para rasul yang meneruskan pengajaranNya. Namun yang paling menonjol dalam pengajan rasulrasul adalah rasul Paulus. Rasul Paulus disebut guru yang ulung. Rasul Paulus mengajar di rumah-rumah tempat ia menumpang, digedung-gedung yang disewanya, di lorong-lorong kota dan di padangpadang, di atas kapal dan di dalam bengkelnya, di pasar dan dalam kumpulan kaum filsuf. Tak ada tempatnya yang dianggap kurang layak untuk menyampaikan beritanya tentang Juruselamat dunia, dan rasul Paulus bayak mengajar melalui surat-surat. ${ }^{10}$

Dalam pengajaran rasul Paulus, ia menggunakan Injil yang belum dalam bentuk tertulis dan juga ia menggunakan kitab-kitab Musa. Pengajaran rasul Paulus mulai berkembang yaitu sejak munculnya jemaat mula-mula. Dalam jemaat mula-mula berdiri atau ada, setelah firman Tuhan sudah disebarkan oleh para rasul dan mereka telah meresponi firman Tuhan yang telah disampaikan. Mereka mulai mengadakan suatu kumpulan, dimana perkumpulanperkumpulan itu, mereka berdoa, ber-

\footnotetext{
${ }^{8}$ Ibid., 5.

${ }^{9}$ Homrighausen, 5 .

${ }^{10}$ Ibid., 6
} 
bicara tentang pengajaran dan perbuatanperbuatan Tuhan Yesus Kristus. Mereka yakin sejak turunnya Roh Kudus, jemaat mereka merupakan Israel baru. Dengan keyakinan yang demikian, sehingga mereka mengambil keputusan untuk mulai berkhotbah dan mengajar. Supaya orang lain percaya kepada Yesus sebagai Penebus dan Tuhan. Setelah orang-orang tersebut bertobat dan mau bergabung dengan mereka, maka mereka mengadakan bimbingan secara khusus. Pemahaman ini kembali dijelaskan oleh Homrighausen, E.G., Enklaar, I.H, bahwa jemaat mula-mula itu mempelajari nubuatan-nubuatan nabi dahulu kala mengenai Yesus Kristus dan mereka juga membaca surat-surat yang diterima dari rasul Paulus dan lain-lain. ${ }^{11}$ Melalui penjelasan di atas memberikan suatu kesimpulan bahwa peran Paulus dalam kegiatan pelayanannya dan pengajarannya tergambar jelas bagimana Paulus selalu disertai kuasa dari Tuhan untuk melakukan semua pelayananya karena Paulus selalu percaya otritas Allah, sehingga semua berjalan sesuai rencana Tuhan.

Pada masa bapa-bapa gereja (100$500 \mathrm{ZB}$ ): Zaman Bersama, situasi yang penuh gejolah dengan muncul berbagai bidat menjadikan masa itu menjadi masa yang sangat menentukan dalam sejarah pengakuan iman Kristen. Mereka dengan tegas berani menantang setiap ajaran sesat dengan bersandar pada otoritas Alkitab. Salah satu sumbangsih dari bapa-bapa gereja adalah kanon Alkitab khususnya Perjanjian Baru (27 kitab), Bapa-bapa gereja ini diberikan julukan sebagai "tokoh-tokoh Injil" karena keteguhan mereka mempertahankan Injil serta jasa mereka dalam merumuskan doktrin yang ada.

${ }^{11}$ Homrighausen., 8.
Oleh karena itu muncul masa Reformasi Gereja ( $\pm 1500-1800 \mathrm{M})$, yang di pelopori oleh Martin Luther, Yohanes Calvin, Ulrich Zwingli. Mereka mengadakan suatu penolakan terhadap ajaran Gereja Katolik Roma, para Reformator dan pengikutnya merumuskan beberapa pokok iman, diantaranya: Tiga dasar Konfensi Reformasi yang disampaikan oleh para Reformator, yaitu: Sola Scriptura, hanya Alkitab firman Allah; Sola Fide, hanya oleh iman manusia dibenarkan; dan Sola Gratia, hanya oleh anugerah manusia diselamatkan. Pengakuan iman Agusburg (6 butir iman Luther). Pengakuan iman Dort (6 butir iman Calvin). Pengakuan iman Wesminster (Pengakuan iman gereja Inggris), dan Pengakuan iman Heidelberg (pokok-pokok pengaran Calvinis). ${ }^{12}$

Dari dasar-dasar iman yang mereka anut, nyata bahwa mereka kembali kepada ajaran para rasul dan bapa-bapa gereja. Oleh karena itu para Reformator juga disebut kaum Injili serta ajaranajaran mereka disebut ajaran Injili. Namun pada abad ke-19 sampai abad ke20, muncul teolog-teolog modern yang dipelopori oleh Karl Barth, yang beranggapan bahwa Alkitab tidak mutlak diterima sebagai wahyu otoritatif, karena banyak kekurangan dan kelemahan. Sehinga dalam ajaran mereka, mereka berusaha untuk membuktikan Alkitab secara ilmiah. ${ }^{13}$ Dari pengajaran teolog modern yang tergolong ajaran sesat, maka muncul ajaran kaum Injili abad ke20 sampai sekarang yang berpatokan pada Reformasi Luther, dkk. Paling tidak kaum Injili masa kini memiliki ciri khas sebagaimana yang diungkapkan Richard Quebedeux yakni; Alkitab adalah firman Tuhan yang tanpa salah dalam naska

\footnotetext{
${ }^{12}$ Homrighausen., 6.

${ }^{13}$ Homrighausen., 6.
} 
aslinya, berkuasa penuh dalam iman dan perbuatan. Perpalingan, yaitu pertobatan dari dosa dan beriman kepada Tuhan Yesus Kristus sebagai satu-satunya Juruselamat. Melaksanakan dengan penuh tanggung-jawab Amanat Agung dari Tuhan Yesus Kristus (Mat. 28:19-20) dan terlibat serius dalam penginjilan. ${ }^{14}$

Selanjutnya kaum Injili juga percaya Paulus telah meletakkan dasar bagi tugas utama mereka dalam Galatia 1:78dan 6:2-5 yaitu: Memberitakan Injil Kristus secara intensif dan berkesinambungan sampai Kristus datang kembali (bnd. Mat. 28:19-20; Mrk. 16:15-16; Luk. 24:47-48; Yoh. 20:21-23; Kis. 1:8); Membela dan mempertahankan kemurnian Injil (Gal. 1:9). Membela dan mempertahankan serta mengajarkan teologi Reformasi yang terangkum dalam 5 pokok yaitu; Sola Scriptura, Sola Fide, Sola Gratia, Sola Cristos, dan Sola Deo Gloria. $^{15}$

Jadi kesimpulannya bahwa seorang pengajar PAK dalam pengajarannya mengakui 5 Pokok teologi Reformasi Sola Scriptura, Sola Fide, Sola Gratia, Sola Cristos, dan Sola Deo Gloria, karena ini semua diajarkan oleh Alkitab yang sekarang dikenal oleh umat kristiani yaitu sebagai firman Tuhan dan terlebih guru PAK perlu mengingat bahwa tugas dan tanggung jawabnya sebagai pengajar itu adalah warisan dari Allah, untuk mengajarkan firman Tuhan yang bukan dalam bentuk lisan lagi, tetapi sudah dalam bentuk tulisan yaitu Alkitab, karena hanya melalui Alkitab manusia dapat mengenal Sang Juruselamat yang abadi yaitu Yesus Kristus.

\footnotetext{
${ }^{14}$ Ibid, 18.

${ }^{15}$ Ibid
}

\section{Alkitab sebagai sumber utama Pengajaran PAK}

Perlu diketahui bahwa Pendidikan Agama Kristen berpangkal pada persekutuan dengan Tuhan. Hal ini sudah dijelaskan dalam Perjanjian Lama. Dalam persekutuan, Allah berbicara kepada manusia melalui firman-Nya dengan tujuan manusia dapat mengenal Allah yang mereka sembah, mengenal rencana keselamatan Allah bagi manusia dan mengenal apa yang dikehendaki Allah bagi manusia, John Benton dan John Peet mengatakan: Kita tidak perlu mencari dalam buku-buku yang lain untuk mengetahui apa yang dipercaya, bagaimana kita perlu bersikap, atau bagaiman kita memahami pengalaman-pengalaman hidup kita; kita tidak boleh mencari dalam buku-buku yang lain karena Alkitab satu-satunya sumber wahyu yang telah Allah berikan kapada kita tanpa salah. $^{16}$

Pemahaman di atas memberikan suatu pengertian kita tidak perlu mencari buku-buku yang lain artinya bahwa buku disini artikan dengan buku-buku yang penulisnya tidak sesuai dengan isi yang ada dalam Alkitab, karena penulispenulis yang memiliki konsep tidak benar, maka mengacu kepda pemikirannya sendiri tanpa melibatkan Alkitab adalah firman Tuhan. Sehingga tidak perlu mencari di luar Alkitab untuk mendapatkan pemahaman yang benar mengenai Allah, atau bagimana hubungan manusia dengan Allah. Oleh sebab itu manusia perlu berusaha untuk memahami dengan baik segala sesuatu yang terdapat di dalam Alkitab itu. ${ }^{17}$

\footnotetext{
${ }^{16}$ John Benton dan John Peet, God's Riches, Kekayaan Kasih Karunia Allah (Surabaya: Momentum, 2003), 6.

${ }^{17}$ Ibid., 7.
} 
Pengajaran Alkitab secara eksposisi artinya berusaha memberitakan isi Alkitab dengan meneliti arti Alkitab secara saksama, baik dengan konteksnya yang berhubungan dengan perikop tersebut, maupun dengan konteks Alkitab secara keseluruhan dan mengaplikasikan kebenaran tersebut dalam hidup manusia. ${ }^{18}$ Inti berita Alkitab bukan hanya pengetahuan tentang banyak hal saja, tetapi selalu bersifat mendorong untuk mengambil bagian dalam keselamatan Allah. Dalam usaha manusia untuk memahami tentang Allah, maka manusia menggunakan filsafat-filsafat, buku-buku sekuler, dan bahkan melalui usaha-usaha lain untuk bertemu dengan Allah, tetapi tidak menemukan Allah yang sesungguhnya. Kebenaran yang diajarkan oleh Alkitab sangat berbeda dengan ajaran-ajaran filsafat modern seperti ateistik, yaitu ajaran yang tidak mengakui adanya Allah, dan bahwa dunia manusia dan semua yang ada di dalamnya, terjadi sendirinya. Ajaran seperti ini yang membuat manusia hidup penuh keraguan dan tanpa arah tujuan. Alkitab mengajarkan Allah ada, merupakan pusat dari segala sesuatu, dan bahwa Ia menciptakan dunia serta mengelar setiap lembaran sejarah-Nya dengan tujuan untuk membawa segala kemuliaan kepada keagungan, kemuliaanNya melalui Tuhan Yesus Kristus (Ef. 1:6, 14; 3:20-21; Fil. 2:10-11). ${ }^{19}$ Alkitab adalah penyataan diri-Nya kepada manusia, Alkitab memaparkan kehendakNya dan rencana-Nya bagi dunia ini. Alkitab berbicara tentang sesuatu yang nyata terjadi di bumi, apa yang dilakukan oleh Yesus di depan murid-murid.

Alkitab juga disebut buku yang mengajarkan tentang cara beriman, tetapi

\footnotetext{
${ }^{18}$ John Benton dan John Peet, 8.

${ }^{19}$ John Benton dan John Peet, 11.
}

dengan tujuan lebih luas yaitu seluruh hidup manusia akan diperbaiki, diperbaharui, disempurnakan dihadapan Allah. Alkitab juga disebut buku tentang persekutuan antara Allah dengan manusia, dan yang lebih istimewa lagi, Alkitab membawa kabar Injil kepada manusia, yaitu "kabar baik" tentang bagaimana Tuhan bertindak dalam sejarah untuk berkomunikasi dengan manusia, untuk menyelamatkan manusia dari dirinya sendri, akibat dari dilema fatal yang disebut dosa. Roma 10:17 mengajarkan bahwa setelah seseorang mendengar Injil keselamatan, ia memiliki iman untuk percaya dan menerima Dia. Apabila ia percaya dan menerima-Nya, timbul iman dari pendengaran dan pendengaran oleh firman Kristus. Billy Joe Daugherty mengatakan, "kita tidak memiliki iman didalam Allah apabila kita terpisah dari firman Allah". ${ }^{20}$

Harun Hadiwijono mengatakan, "firman Allah sebagai alat Roh Kudus untuk memberikan keselamatan dari Kristus kepada orang-orang beriman. Dengan perantaraan firman Allah, Roh Kudus menganugerahkan iman didalam kehidupan orang percaya, dan menguatkan iman yang telah dianugerahkan itu". ${ }^{21}$ Artinya bahwa Alkitab hanya sebagai sarana Allah untuk menyampaikan keselamatan bagi umat manusia melalui iman. "Alkitab sebuah kaca mata yang dapat dipakai oleh manusia untuk melihat Allah melalui apa yang ditulis di dalam kitab suci agar manusia dapat bertemu dengan Juruselamatnya, karena kitab suci memberi kesaksian tentang Dia. Hal ini mungkin terjadi hanya sebab, melalui Roh Kudus kitab Suci itu dapat menjadi firman Allah bagi kita, namun

\footnotetext{
20 Billy Joe Daugherty, Kuasa Iman (Jakarta: Metanoia, 2004), 7.

${ }^{21}$ Harun Hadiwijono, Iman Kristen (Jakarta; BPK Gunung Mulia, 2005), 421.
} 
firman itu dalam Yesus Kristus". 22 Dengan demikian, maka fungsi Alkitab itu bukan memberi informasi, melainkan untuk menolong seseorang mengenal Allah.

Dengan maksud tujuan Alkitab hendaknya diajarkan oleh guru-guru PAK. Eli Tanya mengatakan: Tujuan pengajaran Alkitab bukanlah memberitakan informasi sebanyak mungkin kepada pelajar-pelajar. Ini bukan tujuan akhir dari pengajaran tentang Alkitab. Tujuan sebenarnya dari pengajaran Alkitab adalah agar cerita-carita Alkitab itu relevan dengan situasi hidup pada pelajar. Jadi dalam hal ini bukanlah transmisi fakta-fakta Alkitab dituju melainkan hubungan langsung fakta-fakta dengan situasi murid-murid. ${ }^{23}$

Jadi dapat di-simpulkan bahwa dalam pengajaran Kristen Alkitablah yang menjadi sumber pengajaran utama guru PAK. Alkitablah yang menjadi pengantar seseorang untuk pencaya kepada Allah, rencana-rencana-Nya tentang anugerah keselamatan, rencana anugerah kepercayaan (iman) kepada Yesus Kristus sebagai Juruselamat (2 Tim. 3:15-17; Rm. 10:9; Ef. 2:9-10). Sebab di luar daripada Alkitab sebagai sumber pengajaran, maka pengajaran itu tidak ada jaminan keselamatan yang pasti.

\section{Alkitab sebagai Patokan Pengajaran PAK}

Ketika Alkitab menjadi sumber Pendidikan Agama Kristen, maka Alkitab

22 Sara Lette, The Bible In Cristian Education, 57., dikutip Lowrence O.Richard, Mengajarkan Alkitab secara Kreatif (Bandung: Kalam Hidup, TTP), 18-19.

${ }^{23}$ Eli Tanya, Gereja dan Pendidikan Kristen (Cipanas: STTC, 1999), 15 sendiri yang menjadi patokan/ standar dalam pengajaran Kristen. Hal ini dikarenakan hanya dalam Alkitab manusia menemukan siapa itu Allah dan apa yang dikehendaki oleh Allah bagi manusia, dan apa rencana Allah bagi manusia yang sudah dicemari oleh dosa, (Rm. 3:23; 6:23).

Menurut Dennis Mecallum, "kebanyakan agama mengajarkan bahwa untuk memperoleh keselamatan, manusialah yang menentukan apa yang dilakukannya, dipandangnya berkenan kepada ilah yang disembahnya". ${ }^{24}$ Dengan suatu pengertian bahwa untuk mencapai keselamatan itu manusia harus berusaha secara pribadi. Ini sangat bertentangan dengan perkataan Paulus di dalam Efesus 2:9-10, keselamatan adalah anugerah Tuhan dan itu hanya diperoleh melalu iman dan itu bukan hasil usaha manusia, sehingga jangan memegahkan diri. Ayat inilah yang diimani oleh umat kristiani.

Dalam ajaran Kristen, keselamatan hanya bersumber dari Alkitab, melalui anak tunggal Allah yaitu Yesus Kristus, yang berinkarnasi. Penjelmaan Kristus adalah untuk merukan karya Allah agar manusia diselamatkan. Kitab Roma 3:23 menyatakan, "karena semua orang telah berbuat dosa dan telah kehilangan kemuliaan Allah", sekalipun manusia bertanggungjawab atas setiap perbuatan yang jahat, sebab upah dosa ialah maut, tetapi karunia Allah adalah hidup yang kekal dalam Tuhan Yesus Kristus" (Rm. 6:23). Namun Allah tidak mau melihat manusia untuk menanggung hukuman atau dosanya. ${ }^{25}$ Sebab itu Allah mengutusAnak-Nya Yesus Kristus datang

\footnotetext{
24 Dennis Mecallum, Kekristenan, Iman Masuk Akal, alasan-alasan kuat yang mendasari kepercayaan kepada Kristus (Bandung: Kalam Hidup, 2000), 23.

${ }^{25}$ Ibid., 24.
} 
untuk menanggung dosa manusia. Orangorang Kristen mengatakan bahwa Yesus Kristus adalah satu-satunya jalan, untuk menuju Allah, Kisah Para Rasul 4:12 mengatakan, "keselamatan tidak ada di dalam siapapun juga selain di dalam Dia, sebab di bawah kolong langit ini tidak ada nama lain yang diberikan kepada manusia yang olehnya kita dapat diselamatkan". Suatu padangan yang keliru bahwa kepercayaan tentang Tuhan adalah mengacu pada Tuhan yang sama. Menurut Paul E.Little bahwa, Persamaam dalam agama-agama di dunia ini banyak sekali dibicarakan orang. Banyak orang Kristen berpicik bahwa agamaagama lain pada dasarnya sama dengan agama Kristen, karena agama-agama lain mempunyai tuntutan yang sama dan melakukan hal-hal yang sama dalam kekristenan, namun istilahnya yang berbeda sedikit. Sikap seperti ini, menunjukan bahwa mereka sama sekali tidak mengetahui seluk beluk agama lain. ${ }^{26}$

Penulis berpendapat bahwa apa yang dikatakan Paul E.Little adalah masih ada orang Kristen yang menganggap bahwa ajaran dari agama Kristen dengan agama-agama lain itu sama. Penulis memberikan kesimpulan bahwa anggapan seperti ini adalah anggapan yang salah, karena dari kitab sucinya sudah berbeda, maka tidak mungkin ajarannya sama. Kekristenan menerima Allah yang mencari manusia dan Ia sendiri mengulurkan tangan-Nya untuk menolong manusia. Sedangkan dalam agama-agama lain adalah manusia sendiri yang mencari dan berjuang untuk mencapai atau bertemu dengan.$^{27}$ Oleh karena perbedaan yang amat besar itu, maka ajaran kekristenan dapat mem-

\footnotetext{
26 Paul E.Little, Akal Kekristenan (Bandung: Kalam Hidup, TTP), 116.

${ }^{27}$ Ibid., 118.
}

berikan keyakinan keselamatan hanya melalui iman dalam Yesus kristus.

Dalam pemahaman orang Kristen tentang keselamatan yang diajarkan oleh Alkitab hanya oleh iman kepada Tuhan Yesus, ia diselamatkan. Ini menunjukan bahwa Alkitab sebagai patokan/standar tentang doktrin keselamatan. G.I. Williamson mengatakan: Alkitab mengajarkan doktrin-doktrin ini merupakan salah satu alasan yang kuat bahwa Alkitab adalah firman Allah. "besar perbuatan-perbuatan TUHAN, layak diselidiki oleh semua orang yang menyukainya" (Mzm. 111:2). ${ }^{28}$ Yang dimaksud G. I. Williamson adalah Alkitab terbuka untuk siapapun yang mau menyelidikinya. Tetapi bukan berarti bahwa setiap bagian-bagian dalam Alkitab dibuktikan semua. Mengapa? karena manusia itu sudah sama dengan Allah (pikiran sama), maka Alkitab menjadi batasan dalam setiap penyelidikan-penyelidikan. Artinya setiap penyelidikan terhadap Alkitab tidak menemukan makna yang sesungguhnya, maka itu perlu diimani karena Alkitab itu benar. Dengan demikian, maka perlu percaya dan beriman kepada-Nya karena Ia berkuasa melakukan segala sesuatu jauh melebihi yang manusia minta atau bahkan apa yang ada dalam pikiran manusia. ${ }^{29}$ Calvin memaparkan bahwa untuk dapat mengenal Allah sebagai Pencipta, manusia harus kembali kepada Alkitab. ${ }^{30}$ Calvin menekankan bahwa pengenalan tentang Allah yang sejati, hanya melalui wahyu khusus (Alkitab), karena tanpa melalui Alkitab manusia tidak mungkin mendapatkan gambaran

\footnotetext{
28 G.I.Williamson, The Shorter Catechismus Singkat Westminster (Surabaya: Momentum, 2006), 68.

${ }^{29}$ G.I.Williamson, 68.

${ }^{30}$ http://www.com.org/otoritasAlkitab
} 
Allah yang sempurna. Jadi kesimpulan bahwa yang dimaksud dengan Alkitab sebagai patokan adalah setiap ajaranajaran kristiani berpatokan pada Alkitab dan didasari oleh iman. Setiap ajaran dari manapun yang bertentangan dengan Alkitab dan iman Kristen, perlu diselidiki.

\section{Menangkal Ajaran-ajaran Sesat}

Menurut Alkitab kata menang itu hanya ditujukan kepada Tuhan Yesus ketika Ia menyerahkan nyawa-Nya mati bagi manusia yang berdosa, yaitu ketika Ia berada dalam alam kematian selama tiga hari tiga malam, Ia telah bangkit kembali dari antara orang-orang mati dan telah mengalahkan maut. Jadi artinya dengan mengakui adanya otoritas Alkitab dapat mengalahkan ajaran-ajaran yang tidak sesuai kebenaran Allah. Bultmann hanya tertarik dengan berita yang ada dalam Alkitab dan tidak mengakui otoritasnya, sedangkan menurut Crampton: Sebenarnya, Bultmann mengerti secara tepat kebenaran Alkitab, seseorang melakukan "demitologisasi" peniadaan ajaran Perjanjian Baru mengenai Kristus. Kristus lebih dilihat sebagai tokoh mitos ketimbang sebagai tokoh historis dalam Alkitab, dan mengasumsikan bahwa Alkitab memerlukan sesuatu penerjemahan yang bersifat "ilmiah" modern supaya dapat berguna. ${ }^{31}$

Jelaslah bahwa anggapan seperti ini salah, karena tidak mungkin manusia bisa mengenal dan percaya Allah yang telah menyetakan diri-Nya di dalam Yesus Kristus kalau hanya menerima Alkitab sebagai karya ilmiah semata. Dalam usaha manusia mencari dan mau mengenal Allah yang sesungguhnya, maka

${ }^{31}$ Ibid., 71. manusia hanya mengandalkan penelitianpenelitian (mengandalkan logikanya). A.W.Tozer mengatakan, "hampir semua orang Kristen di seluruh dunia beranggapan rendah tentang Allah, dan ini merupakan penyebab dari kejahatankejahatan yang lebih kecil yang banyak terdapat dianatara kita. Sebagai akibatnya adalah muncullah filsafat-filsafat". ${ }^{32}$

Perkataan rasul Paulus kepada jemaat di Kolose, "hati-hatilah, supaya jangan ada yang menawan kamu dengan filsafat yang kosong dan palsu menurut ajaran turun temurun dan roh-roh dunia, tetapi tidak menurut Kristus" (Kol. 2:8). Anggapan seperti ini adalah anggapan yang salah. Untuk mengenal iman Kristen melalui historis yang sesungguhnya bukan berdasarkan logika, tetapi berdasarkan anugerah Allah melalui Roh Kudus. "apabila Roh hendak memperkenalkan seseorang kepada sesuatu yang berbeda di luar alam pengetahuan manusia, Roh itu memberitahukan bahwa hal seperti sesuatu yang sudah diketahui, tetapi Roh selalu berhati-hati sekali dalam mengungkapkan lukisan-Nya supaya manusia tidak terlalu harafiah". ${ }^{33}$

Stephen Tong mengatakan dalam iman Kristen sejati yang dipelopori oleh Martin Luther, bahwa iman adalah anugerah yang tidak berdasarkan jasa manusia, tidak berdasarkan kekuatan manusia, tidak berdasarkan segala kebajikan/usaha dari manusia, karena iman adalah sesuatu pemberian dari Allah secara cuma-cuma. ${ }^{34}$ Dengan suatu pengertian dimaksud oleh Tong bahwa yang dianugerahkan adalah karya penyelamatan yang telah dikerjakan oleh Yesus Kristus sebagai utusan Allah bagi manusia yang telah berdosa. Artinya

\footnotetext{
32 A.W.Tozer, Mengenal yang Maha Kudus (Bandung: Kalam Hidup, 1999), 5.

${ }^{33}$ A.W.Tozer, 15.

${ }^{34}$ Stephen Tong, 17.
} 
pengakuan melalui mulut dan percaya dalam hati bahwa Yesus Kristus adalah Tuhan yang mengerjakan keselamatan. Di dalam Alkitab juga sudah menjelaskan bahwa di kolong langit ini tidak ada nama lain yang sanggup menyelamatkan, hanyalah Yesus, (Kis. 4:12).

Untuk menangkal ajaran-ajaran sesat yang berkembang saat ini, secara khusus tentang Yesus yang diimani oleh umat kristiani, itu perlu diliht di dalam Alkitab, karena Alkitab mengajakan bahwa ada ajaran-ajaran sesat. Salah satu contoh ungkapan imam-imam kepala dan orang Farisi dihadapan Pilatus tentang Yesus adalah penyesat (Mat. 7:28), waspadalah supaya kamu jangan disesatkan, sebab akan ada nabi-nabi palsu (Luk. 12:8). Artinya bahwa orang-orang Kristen tidak ragu lagi terhadap ajaranajaran yang menyesatkan pada masa kini. Selayaknya iman Kristen kembali kepada ajaran otoritas Alkitab. Menurut Derek Prince, seperti yang dikatakan oleh rasul Paulus bahwa di dalam Alkitab, kehidupan orang beriman diumpamakan seperti sebuah bangunan gedung. ${ }^{35}$ Misalnya Yudas 1:20, "akan tetapi kamu, saudarasaudaraku yang kekasih, bangunlah dirimu sendiri atas dasar imanmu yang paling suci dan berdoalah dalam Roh Kudus", ungkapan Paulus kepada jemaat di Korintus, "karena kami adalah kawan sekerja Allah; kamu adalah ladang Allah, bangunan Allah. Sesuai dengan kasih karunia Allah, yang dianugerahkan kepadaku, aku sebagai seorang ahli bangunan yang cakap telah meletakan dasar, dan orang lain membangun terus di atasnya. Tetapi tiap-tiap orang harus memperhatikan, bagaimana ia harus membangun di atasnya”. (1Kor. 3:9-10).
Demikian juga dalam perkataan Paulus kepada jemaat di Efesus, "didalam Dia kamu juga turut dibangun menjadi tempat kediaman Allah, didalam Roh" (Ef. 2:22), "dan sekarang aku menyerahkan kamu kepada Tuhan dan kepada firman kasih karunia-Nya, yang berkuasa membangun kamu dan menganugerkan kepada kamu bagian yang telah ditentukan bagi semua orang yang telah dikuduskanNya",

Dari pemahaman atas sudah jelas bahwa seseorang yang beriman, diumpamakan sebagai sebuah gedung yang sedang dibangun. Karena itu untuk menentukan kuat tidaknya sebuah bangunan, dilihat dari pondasinya, apabila pondasinya kuat, maka bangunan itu akan berdiri teguh. Maka yang menjadi pondasi bagi iman Kristen adalah Yesus Kristus, karena tidak ada seorangpun yang dapat meletakan dasar lain daripada dasar yang telah diletakan oleh Yesus Kristus (1 Kor. 3:11), sebab ada tertulis dalam Alkitab sesungguhnya, Aku meletakkan di Sion sebuah batu yang terpilih, sebuah batu penjuru yang mahal..., (1 Pet. 2:6; bnd Yes. 28:16). Alkitab menjelaskan kebenaran yang hakiki ini, yang sudah pasti menjadi dasar utama kehidupan dari iman orang Kristen adalah Yesus Kristus sendiri, bukan sesuatu hal atau pribadi yang lain.

Jadi kesimpulan bahwa untuk menangkal ajaran-ajaran sesat itu hanya berdasarkan tiga poin yaitu, pertama. Mengutamakan kuasa dari pada Alkitab, kedua. Mengutamakan tujuan utama pendidikan Kristen yaitu membawa peserta didik untuk mengenal Allah, ketiga. Percaya dan mengakui Yesus Kristus adalah Juruselamat manusia. 35 Derek Prince, Dasar Iman (Jakarta: Imanuel,
1996), 9. 


\section{Membawa Perubahan Karakter bagi Guru dan Peserta Didik}

Otoritas Alkitab menjadi bagian penting bagi kehidupan manusia dan mempengaruhi kehidupan kini bagi para pendengar dan pembacanya. Pengaruh yang dimaksud disini adalah kuasa Alkitab mampu mengubah karakter dan kehidupan para pengajar dan para peserta didik, asal mau taat dan patuh, firman Allah itu kekal. Stephen Tong mengatakan, "Allah menjanjikan satu Juruselamat (Tuhan Yesus), yang akan menjadi penolong dan yang akan berdiri antara Allah dan manusia berdosa untuk menyelesaikan penyelewengan dan dosa manusia". ${ }^{36}$

Jika seandainya Allah tidak menyatakan diriNya melalui Anak-Nya, maka manusia tidak mengetahui apa-apa tentang Allah, Allah tetap menjadi satu rahasia. Untuk itu Allah memakai firmanNya, karena firman itu menghidupkan, menciptakan, berkuasa (Kej. 1:3, 6; Mzm. 3:4,6,8; Yoh. 1:1,14). Yesus Kristus bukan hanya memberikan keselamatan kepada manusia, akan tetapi Yesus sebagai guru pengajar kebajikan, pemberi teladan moral, atau memberikan pengajaran-pengajaran etika. ${ }^{37}$ Inilah yang diajarkan umat kristiani berdasarkan Alkitab, yaitu setiap yang mengaku dengan mulut dan percaya dalam hati bahwa Yesus adalah Tuhan, ia akan selamat (Rm. 10:9), dan inilah yang disebut iman..., (Ibr. 11:1), dan iman itu identik dengan perbuatan yang diajarkan oleh Tuhan Yesus, karena jika iman tidak disertai perbuatan, maka iman itu pada hakekatnya adalah mati, Yakabus 2:19.

\footnotetext{
36 Stephen Tong, Yesus Kristus Juruselamat Dunia (Surabaya: Momentum, 2004), 73.

${ }^{37}$ Ibid., 82.
}

Jadi penulis menyimpulkan bahwa ketika seorang pengajar Kristen memahami Alkitab dan menerapkan dalam pengajarannya dengan pasti, peserta didik akan diberkati. Artinya Alkitab membawa perubahan pada pengajar dan peserta didik. Seperti perkataan Paulus kepada penatua di Efesus, "dan sekarang aku mengarahkan kamu kepada Tuhan dan kepada firman kasih karunia-Nya, yang berkuasa membangun kamu ...," (Kis. 20:32).

\section{Perubahan karakter bagi Guru PAK}

Dengan pasti bahwa seorang pengajar Kristen adalah orang yang beragama Kristen dan sudah mengalami perubahan karakter, dan yang dimaksud dengan perubahan karakter disini adalah pertobatan. Menurut kamus teologi "tobat" bearti berbali. Maksudnya yang dilalui sekarang adalah keliru dan berbalik mengikuti jalan yang baru. $^{38}$ Pemahaman yang lebih jelas lagi berhubungan dengan kelahiran kembali, inilah yang membedakan pengajar Kristen dengan pengajar agama-agama lain. Kata kelahiran kembali itu muncul dalam percakapan Yesus dengan Nikodemus (Yoh. 3:3-8) dan maksud ungkapan Yesus tentang kelahiran kembali yaitu dilahirkan kembali dari air dan Roh (ay. 5) dan Roh yang dimaksud adalah Allah sendiri yaitu Yesus Kristus (Yoh. 4:24). Kata ini selalu dipakai dalam pengajaran rasul Paulus, namun rasul Paulus merubah dengan istilah yang dipakai oleh Yesus dalam pengajaranNya yaitu percayalah kepada-Ku. Misalnya Kisah Para Rasul 16:31. Mengaku dan percaya kepada Injil itu adalah pekerjaan Roh Kudus (1 Pet. 1:23;

\footnotetext{
${ }^{38}$ R. Soedarmo, Kamus Istilah Teologi (Jakarta: BPK Gunung Mulia, 2009), 96.
} 
Yak. 1:13). Dan dengan Roh Kudus yang sama itu masuk ke dalam batin manusia untuk mengajarkan kelahiran kembali, hati yang tertutup akan dibuka-Nya, apa yang keras dilembutkan-Nya, apa yang tidak bersunat disunat-Nya, dalam kehendak dituangkan-Nya sifat-sifat baru (kehendak hidup yang baik, bersedia menghasilkan yang baik). Untuk memiliki kepribadian yang sesuai kehendak Allah, guru PAK diharapkan menjadi teladan bagi peserta didik.

J. M. Prince mengatakan: Syarat yang penting bagi seorang guru adalah kepribadiannya sendiri. Sebuah teladan lebih berharga dari pada seratus kali nasihat. Perubahan seseorang lebih berpengaruh dari pada perkataannya, kebenaran yang diwujudkan adalah satusatunya kebenaran yang berpengaruh. Oleh karena itu setiap guru hendaknya merasa bahwa dirinyalah pelajaran yang terbaik. ${ }^{39}$

Kebenaran yang dimaksud J.M.Prince adalah kebenaran Kristus yang dikerjakan oleh Roh Kudus di dalam pribadi tersebut. Dengan demikian, seorang pengajar kristen sebelum mengajarkan isi Alkitab kepada peserta didik, maka secara pribadi terlebih dahulu merasakan keuntungan dan perubahan dari kuasa Allah melalui firman Tuhan, yakni adanya pertobatan atau hidup baru di dalam Yesus dan melalui pengajrannya terpancar kebenaran Yesus Kristus yang menjadi tujuan pengajarannya.

\section{Perubahan Karakter pada Peserta Didik}

Istilah karakter dihubungkan dan dipertukarkan dengan istilah etika, ahlak, dan atau nilai dan berkaitan dengan kekuatan moral, berkonotasi positif,

39 J. M. Prince, Yayasan Gunung Agung (Bandung: Lembaga Literatur Baptis, 1997), 5. bukan netral. Sedangkan Karakter menurut Kamus Besar Bahasa Indonesia (2008) merupakan sifat-sifat kejiwaan, akhlak atau budi pekerti yang membedakan seseorang dari yang lain. ${ }^{40}$ Dengan demikian karakter adalah nilainilai yang unik-baik yang terpateri dalam diri dan terejawantahkan dalam perilaku. Karakter secara koheren memancar dari hasil olah pikir, olah hati, olah rasa dan karsa, serta olahraga seseorang atau sekelompok orang. Dalam lingkup pendidikan kristen, perlu mempelajari tentang hidup yang baik menurut kebenaran Allah. Hal ini seperti doktrin pembenaran menurut Luther, Kebenaran Allah yang dikomunikasikan Perjanjian Baru khususnya Paulus harus dipakai sebagai kebenaran yang diperhitungkan kepada manusia yang berdosa. Dari dirinya sendiri, seseorang tidak disebut benar kecuali ia dibenarkan oleh Allah sendiri. Dengan cara bagaimanakah Allah membenarkan manusia berdosa? Stephen Tong mengatakan, hidup ini merupakan pekerjaan Roh Kudus melalui firman yang kita kabarkan, melalui Injil yang kita tegaskan sebagai pusat iman, kita melahirkan mereka melalui kuasa Injil dan firman oleh Roh Kudus di dalam kuasa Allah, setelah itu kita mendidik mereka ke dalam karakter Kristen. ${ }^{41}$

Inti dari Pendidikan Agama Kristen adalah mengatakan kehendak Allah melalui Alkitab. Menurut Ki Dong Kim "Allah menyatakan kepada umat manusia hal-hal yang hendak Ia katakan dan itulah yang disebut kehendak Allah". ${ }^{42}$ Kehendak itu hanya di dalam Alkitab, karena itu rasul Paulus berkata kepada Timotius "segala tulisan diilhamkan Allah memang bermanfaat untuk me-

\footnotetext{
${ }^{40} \mathrm{KKBI}$,

${ }^{41}$ Stephen Tong, 26.

${ }^{42} \mathrm{Ki}$ Dong Kim, Doktrin Keselamatan(Jakarta: Berea, 2009), 49.
} 
ngajar, untuk menyatakan kesalahan, untuk memperbaiki kelakuan dan untuk mendidik orang dalam kebenaran" (2 Tim. 3:16), maka pengajaran Alkitab harus relevan dalam kehidupan. Dan pengajaran bertujuan agar firman Tuhan berbicara kepada murid dan bertemu dengan Tuhan Yesus. ${ }^{43}$ Yohanes 8:5, Tuhan Yesus berfirman "Aku berkata kepadamu, sesungguhnya barang siapa yang menuruti firman- $\mathrm{Ku}$, ia tidak akan mengalami maut sampai selamalamanya". Hal yang sama juga dikatakan Tuhan Yesus, "jika seorang mengasihi $\mathrm{Aku}$, ia akan menuruti firman-Ku dan BapaKu akan mengasihi dia dan Kami akan datang kepadanya dan diam bersamsama dengan dia" (Yoh. 14:23).

Homrighausen mengatakan, seorang guru PAK bertanggungjawab atas hidup rohani muridnya, ia wajib membina dan memajukan hidup rohani murid, karena Tuhan Yesus sudah memberikan perintah kepadanya yaitu, pelihara segala anak, dan domba-domba$\mathrm{Ku}$ gembalakan segala domba-Ku!". ${ }^{44}$ Maksud dari Homrighausen, E.G., Enklaar, I.H, adalah guru bertanggung jawab untuk menanamkan paradigma peserta didik tentang pengetahuan mengenai kehendak Allah sesuai kebenaran Alkitab. Tujuan guru Kristen mengajarkan Alkitab kepada peserta didik agar bertemu dengan Allah secara pribadi di dalam Yesus Kristus, jika dalam pertemuan itu peserta didik menyadari akan dosanya dan mau bertobat, lalu percaya kepada Yesus Kristus yang telah mati untuk menanggung dosa manusia dan bangkit dari kematian dengan tujuan memberi jaminan keselamatan bagi setiap orang yang percaya kepada-Nya.

\footnotetext{
${ }^{43}$ Eli Tanya, 24.

${ }^{44}$ Homrighausen, dkk, 64.
}

Bukti kelahiran kembali dan atau bertobat dikerjakan oleh Allah melalui firman-Nya. Homrighausen, E.G., Enklaar, I. H, mengatakan, berdasarkan tujuan pendidikan Kristen untuk membina persekutuan pribadi peserta didik dengan Tuhan Yesus. Oleh sebab itu pengajaran agama seyogianya merangkum pengajaran, ibadat bersama, persekutuan Kristen satu sama yang lain, dan kesempatan untuk melayani Tuhan dengan sesama manusia. ${ }^{45}$

Jadi yang dimaksud oleh penulis perubahan karakter pada peserta didik adalah para peserta didik sudah mengerti dan mengetahui rencana Allah bagi dirinya melalui Alkitab, dan menyadari bahwa dirinya adalah manusia berdosa, maka perlu pengampunan dalam Yesus dan mau meneladani Yesus. Dari sudut pandang kepercayaan peserta didik, sudah bisa mengambil keputusan untuk percaya dan menerima Tuhan Yesus sebagai Juruselamat dalam pribadinya. Secara khusus seorang guru PAK dalam tugasnya membentuk karakter Kristen, membutuhkan kasih yang sungguhsungguh, keadilan yang tegas, dan kebijaksanaan serta keberanian mengajarkan semuanya bagi peserta didik.

Pengajaran guru PAK dengan bertujuan untuk membawa atau memberikan pemahaman kepada peserta didik agar percaya dan setia kepada Tuhan. Sadar atau tidak sadar peserta didik itupun tidak terlepas dari situasi sukacita dan dukacita, di sinilah peran guru PAK berperan untuk menyampaikan firman Tuhan dan selalu memberikan kekuatan saat menghadapi penderitaan atau masalah. Tuhan berkata: Janganlah takut, sebab aku telah menebus engkau, Aku telah memanggil engkau dengan namamu, engkau ini kepunyaan-Ku. Apabila

\footnotetext{
${ }^{45}$ Ibid., 154.
} 
engkau menyeberang melalui air, Aku akan menyertai engkau, atau melalui sungai-sungai, engkau tidak akan dihanyutkan; apabila engkau berjalan melalui api, engkau tidak dihanguskan, dan nyla api tidak akan membakar engkau. Sebab Akulah TUHAN, Allahmu, Yang Maha Kudus, Allah Israel, juruselamatmu, Yesaya 43:1b-3.

Yesus membawa kesembuhan, kasihNya memelihara dan menopang, serta memberikan satu pengharapan bagi orang percaya. Marilah kepada-Ku semua yang letih lesu dan berbeban berat. Aku akan memberi kelegaan kepadamu. Pikullah yang Kupasang dan belajarlah pada-Ku, karena Aku lemah lembut dan rendah hati dan jiwmu akan mendapat ketenangan, Matius 11:28-30. Martin, dkk., mengatakan, "Yesus mengajar orang-orang percaya tentang bagaimana berjalan bersama dengan Dia dalam kehidupan memikul kuk-Nya. Mereka berjalan untuk hidup sebagaimanaYesus telah hidup, dan berjalan bagaimana menghadapi dan mengatasi masalahmasalah kehidupan bersama dengan RohNya yang mendiami hati orang percaya". "Dari uraian di atas dapat dipahami bahwa setiap penderitaan yang dialami oleh setiap peserta didik yang sudah percaya kepada Yesus Kristus, guru dapat menguatkan, mengajarkan, merendahkan diri, taat, agar tetap percaya kepada Tuhan.

\section{Meningkatkan Iman Kristen}

Iman Kristen adalah tindakan seseorang yang mempercayakan dirinya kepada Tuhan Yesus Kristus untuk

46 Martin dan Deidre Bodgan, Bimbingan Berdasarkan Firman Tuhan (Bandung: Kalam Hidup, 1997), 30. menyelamatkan. ${ }^{47}$ Artinya bahwa iman harus disertai tindakan yang nyata lahir dari diri sendiri dan ketergantungan sepnuh pada Tuhan.

Peningkatan iman Kristen, hal seperti ini tidak dapat diukur atau ditentukan secara ilmiah, tetapi Alkitab mengajarkan bahwa dari tingkah laku dan perbuatannya akan terlihat. Hidup sebagai orang Kristen, "mempunyai tanggung jawab melakukan segala usaha untuk menjalani kehidupan sebagaiman layaknya orang-orang Kristen. Dengan demikian, ditemukan banyak perintah kepada orang Kristen dalam Perjanjian Baru" (1 Pet. 1:13-15). ${ }^{48}$ Namun pada saat manusia menanggapi dengan positif dan mematuhinya, menurut Alkitab, ini merupakan pekerjaan Allah bagi orang percaya (bnd. Fil.2:13-15).

Bertumbuhnya iman seseorang dalam Tuhan hanya melalui pendengaran oleh firman Kristus, Roma 10:17. Menurut Bruce Milne mengatakan, "iman mendasari seluruh pengalaman Kristen sejati. Tanpa iman 'tidak mungkin orang berkenan kepada Allah' (Ibr. 11:6). Iman berarti kepercayaan akan kebenaran Kristus yang disalibkan dan telah bangkit". ${ }^{49}$ Oleh karena hal ini merupakan tanggung jawab orang Kristen secara pribadi dihadapan Allah dan Kristus. Sehingga dengan jelas bahwa dasar iman orang Kristen adalah Yesus Kristus "yang telah diserahkan karena pelanggaran kita dan dibangkitkan karena pembenaran kita" (Rm. 4:25, bnd. Yoh, 1:12, 3:16; Kis. 6:30-31; Rm. 10:9). Iman kepada Kristus adalah komitmen kepada Dia yang telah mati dan telah bangkit bagi orang percaya, artinya dipersatukan

\footnotetext{
${ }^{47}$ Harun Hadiwijono, Iman Kristen (Jakarta: BPK Gunung Mulia, 2005), 8.

${ }^{48}$ John Beriton dan John Peet, 15.

${ }^{49}$ Bruce Milne, Mengenali Kebenaran (Jakarta: BPK Gunung Mulia, 2003), 259.
} 
dengan Krisrus. ${ }^{50}$ lebih jelas lagi yaitu iman adalah persekutuan dengan Kristus, oleh Roh Kudus dalam keseluruhan pribadi-Nya dan itu berarti bahwa semua orang Kristen, walaupun iman mereka masih baru dan belum matang, sudah mati dan bangkit bersama Kristus dan akan mendapat bagian dalam kemuliaan Kristus. ${ }^{51}$ Namun dalam pemahaman iman Kristen yang benar adalah kembali kepada Alkitab, yaitu ketika Tuhan Yesus bertanya kepada Simon Petrus, menurut kamu siapa Aku? Simon Petrus dengan berani tampil mengucapkan kalimat yang begitu kental mewakili orang Kristen sejati dari segala zaman, "Engkau adalah Kristus, anak Allah yang hidup". ${ }^{52}$ Ungkapan Petrus dengan keyakinan menguatkan orang-orang percaya" yaitu kamu yang dipelihara oleh kekuatan Allah karena imanmu sementara kamu manantikan keselamatan yang telah tersedia untuk dinyatakan pada zaman akhir", 1 Pet. 1:5.

Ketika orang Kristen percaya Yesus Kristus sebagai Juruselamat, maka dia juga percaya kuasa dari firman Tuhan, karena di dalam Alkitab penulis telah menyingkapkan perkataan-perkataan Allah, yang mana Yesus menyatakan "Setiap orang yang mendengar perkataan$\mathrm{Ku}$ ini dan melakukannya, ia sama dengan orang yang bijaksana, yang mendirikan rumahnya diatas batu, kemudian turunlah hujan dan datanglah banjir, lalu angin melanda rumah itu tidak rubuh sebab didirikan di atas batu. Sebab setiap orang yang mendengarkan perkataan-Ku dan tidak melakukannya, ia sama dengan orang-orang yang bodoh mendirikan rumah di atas pasir. Kemudian turunlah hujan dan datanglah

\footnotetext{
${ }^{50}$ Ibid, 260.

${ }^{51}$ Ibid, 628.

${ }^{52}$ Stephen Tong, Siapakah Kristus? Sifat dan Karya Kristus (Surabaya: Momentum, 2005), 77.
}

banjir, lalu angin melanda rumah itu, sehingga rubuhlah rumah itu dan hebatlah kerusakannya", Mat. 7:24-27. Stephen Tong mengatakan, "Perjanjian Lama dan Perjanjian Baru dasar iman kita, apa yang tidak sesuai dengan apa yang dicatat di dalam Alkitab jangan diterima! Karena iman kita berdasarkan firman yang tertulis oleh para nabi dalam Perjanjian lama dan para rasul dalam Perjanjian Baru dan keduanya itulah yang menjadi satu pertanggung-jawaban bagi iman kita". ${ }^{33}$ Jadi dalam peningkatan iman Kristen itu hanya dapat diukur dalam Alkitab, yaitu rajin membaca Alkitab, karena ketika ia makin banyak membaca Alkitab, maka makin banyak pengetahuannya tentang Allah. Sehingga kehidupan imannya akan bertumbuh sesuai rencana dan kehendak Allah bagi dirinya secara pribadi.

\section{Daftar Pustaka}

Alkitab. Jakarta: Lembaga Alkitab Indonesia, 2009.

Tozer, A.W, Mengenal Yang Maha Kudus. Bandung: Kalam Hidup, 1999.

Benton John dan Peet John, God's Riches, Kekayaan Kasih Karunia Allah. Surabaya:

Browning,W.R.F, Kamus Alkitab. 2007.

E. G Homrighausen., I. H Enklaar, Pendidikan Agama Kristen. Jakarta: BPK Gunung Mulia,

E.Little Paul, Akal Kekristenan. Bandung: Kalam Hidup, TTP. Hadiwijono Harun, Iman Kristen. Jakarta: BPK Gunung Mulia, 2005.

${ }^{53}$ Ibid 
Joe Daugherty Billy, Kuasa Iman. Jakarta: Metanoia, 2004.

Kim Dong Ki, Doktrin Keselamatan. Jakarta: Berea, 2009.

Lette Sara, The Bible In Cristian Education, dikutip Lowrence O.Richard, Mengajarkan

Martin dan Deidre Bobgan, Bimbingan Berdasarkan Firman Tuhan. Bandung: Kalam Hidup, 1997.

Meade Starr,Treaning Harts Teching Minds. Surabaya: Momentum, 2004.

Mecallum Dennis, Kekristenan, Iman masuk Akal, alasan kuat yang mendasari kepercayaan kepada Kristus. Bandung: Kalam Hidup, 2000.

Milne Bruce, Mengenali Kebenaran. Jakarta: BPK Gunung Mulia, 2003.

Prince Derek, Dasar Iman. Jakarta: Imanuel, 1996.

Prince J.M, Yayasan Gunung Agung. Bandung: Lembaga Literatur Baptis, 1997.

R.W. Stott John, Memahami Isi Alkitab, Jakarta: Persekutuan Pembaca Alkitab, 1994.

Riemer G, Ajarlah Mereka, Pedoman Ilmu Katekisasi. Jakarta: Yayasan Komunikasi Bina Kasih/OMF, 1998.

Ricahard O. Lawrence, Mengajarkan Alkitab secara Kreatif. Bandung: Kalam Hidup, TTP.

Tanya Eli, Gereja dan Pendidikan Kristen. Cipanas: STTC, 1999.

Tim Penyusun, KBBI. Jakarta: Balai Pustaka, 2002.

Tong Stephen, Seri Teologi Reformasi dan TeologiSu. rabaya: Momentum, 2009.

Tong Stephen, Siapakah Kristus? Sifat dan Karya Kristus. Surabaya: Momentum, 2005.
Tong Stephen, Yesus Kristus Juruselamat Dunia. Surabaya: Momentum, 2004.

Williamson G.I, The Shorter Catechismus Singkat Westminster. Surabaya: Momentum, 2006.

http://jiwasuci.blogspot.com/2008/04/sifa t-sifatAlkitab-html

http://www.com.org/otoritasAlkitab 